\title{
CONSUMERS HEALTH AND SAFETY ON THE INTERNET BASED MEDICAL CONSULTATION
}

\author{
Norma Sari* \\ Business Law Department, Faculty of Law, Ahmad Dahlan University, Yogyakarta \\ Pramuka Street No.2, Sidikan, Umbul Harjo Yogyakarta 55161
}

\begin{abstract}
The rise of the internet-based medical consultation has opened not only opportunities for consumers easily obtaining medical services but also put them at risk for mistreatment, misunderstanding or taking a wrong medication to be anticipated. This research concerns on how the internet-based medical consultation affects to the health and safety of the consumers. There are several identified legal issues have to be paid attention as follow: (i) the benefit and shortcoming of using internet-based medical consultation, (ii) inter-related and overlapped interest of the parties, (iii) consumer health and safety, (iv) consumer rights, and (v) dispute settlement.
\end{abstract}

Keywords: consumer, internet-based, medical consultation.

\section{Intisari}

Pertumbuhan konsultasi pengobatan berbasis internet telah membuka peluang tidak hanya bagi konsumen. Kemudahan mendapatkan pelayanan medis tetapi juga menempatkan mereka pada risiko kesalahan perawatan, kesalahpahaman atau kesalahan dalam pemberian obat sehingga hal ini harus diantisipasi. Penelitian ini menjelaskan mengenai konsultasi pengobatan berbasis internet yang mempengaruhi kesehatan dan keselamatan konsumen. Ada beberapa masalah hukum yang harus diperhatikan dan diidentifikasi menjadi sebagai berikut, yakni: (i) manfaat dan kelemahan menggunakan konsultasi pengobatan berbasis internet, (ii) hubungan dan tumpang tindih kepentingan para pihak, (iii) kesehatan dan keselamatan konsumen, (iv) hak-hak konsumen, dan (v) penyelesaian sengketa.

Kata Kunci: konsumen, berbasis internet, pelayanan medis.

\section{Pokok Muatan}

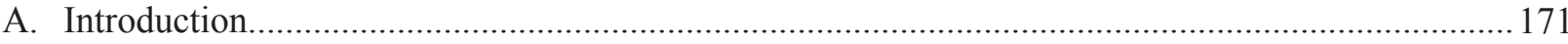

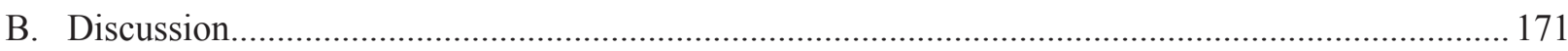

1. The Internet-based Medical Consultation: The New Way of Medical Consultation................... 171

2. The Benefit of Using Internet-based Medical Consultation........................................................ 172

3. Shortcoming of Using Internet-based Medical Consultation.................................................... 173

4. Physicians, Pharmacist, Pharmaceutical Companies, Web Hosting, and Governments:

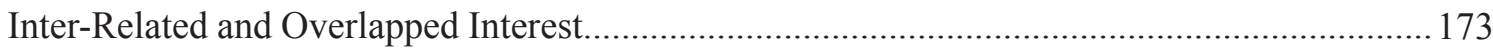

5. Consumer's Right on the Internet-based Medical Consultation.................................................176

6. Dispute Settlement between Consumers to Other Parties: Implementation on Which

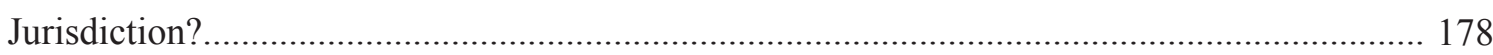

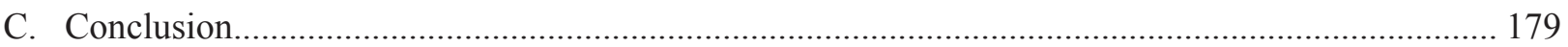




\section{A. Introduction}

The new model of human interaction is characterized by the emergence of the internet as an instrument that connecting people from all over the world at the same time. The growth of the internet as the outcome of evolution process of communication and information technology, penetrated into various field such as economic, political, social, and including health service. Health services are the most visible part of any health system. Health services are divided into promotion, prevention, treatment or rehabilitation, which may be delivered either at home, the community, the workplace, or in health facilities. Effective health service delivery depends on some key resources: motivated staff, equipment, information and finance, and adequate drugs. Improving access, coverage and quality of health services also depends on the ways services are organized and managed, and on the incentives influencing providers and users. ${ }^{1}$

Symbiotic mutualism between the development of the information and communication technology and health service creates the internet-based health service on facilitating health provider and user in enhancing the higher level of human health. This good relationship is a positive side to be developed continuously by reducing the risks. Concerning the issue of consumer's health and safety in medical consultation through the internet, it should have to consider the major priorities of consumer's protection.

\section{B. Discussion}

1. The Internet-based Medical Consultation: The New Way of Medical Consultation

The growth of the internet over the last decade as a medium of information and communication technology is not unsurprisingly provided a foundation for the growth of direct-to-the-public online sales of products and services. The term of the internet-based medical consultation has no exact definition. This term arise when the interaction on medical consultation is provided by the internet.
The pattern can be perpetuated through email or online chatting. The writer is trying to constraint the term the internet-based medical consultation as the model of medical consultation offered by web hosts via providers where some of them are owners of drug shops, some are parts of Pharmacy Company which sells their product via online medium on the website.

The other term is Online Pharmacies, internet Pharmacies or Mail Order Pharmacies that operate over the internet and send the orders to customers. Many such pharmacies are, in some ways, similar to community pharmacies; a primary difference is the method by which the medications are requested and received. Some customers consider this to be more convenient than traveling to a community drugstore, in the same way as ordering goods online rather than going to a store. ${ }^{2}$

There are some different types of selling drugs via online store. While many internet pharmacies sell prescription drugs only with a prescription, some do not require a pre-written prescription. In some countries, this is because prescriptions are not required; depend on the categories of drugs. Some customers order drugs from such pharmacies to avoid the inconvenience of visiting a doctor or to obtain medications their doctors were unwilling to prescribe. Many websites employ their own inhouse physicians to review the medication request and write a prescription accordingly. Some websites offer medications without a prescription or a doctor review. This practice has been criticized as potentially dangerous, especially by those who feel that only doctors can reliably assess contraindications, risk/benefit ratios, and the suitability of a medication for a specific disease. Pharmacies offering medication without requiring a prescription and doctor review or supervision are sometimes fraudulent and may supply counterfeit and ineffective and possibly dangerous medicines. ${ }^{3}$

Many internet-based pharmacies provide online consultations as the first step towards sell- 
ing prescribed medicines online. The consultations usually require that a potential customer fill out an online questionnaire. A typical online consultation questionnaire may consist of three parts. The first part asks for personal details such as name, address, and contact telephone numbers, date of birth, height, body weight, and gender. The second part of the questionnaire asks about medical history including whether a particular drug requested has been used before, what drugs are currently being taken, a history of allergies and side-effects to certain medicines, what complaint is the drug requested for, and whether the customer has suffered from a range of conditions such as heart disease, kidney disease, liver disease, diabetes, epilepsy, hypertension, and asthma. The third part asks for the payment details and shipping information. After the questionnaire is completed, it is then reportedly evaluated by a licensed physician/doctor affiliated to the pharmacy in order to either approve or decline a prescription request. If a request is approved, a prescription is written by the physician then sent to the pharmacy for dispensing and shipping of the medication. ${ }^{4}$

2. The Benefit of Using Internet-based Medical Consultation

\section{a) A wider range of consumer}

Online medical consultation makes a wider range of consumer from all over the world. There is no limitation to reach consumer as far as the internet connection is available. Wherever and whenever the consumer are connected to the internet, he or she can access for counselling of medication easily. This means that the consumer will reach widely than a traditional drug store. ${ }^{5}$

\section{b) Saving the Budget}

Budget calculation is the most important element on the pharmaceutical industry especially on marketing their product. By using the internet as a tool of selling product, this is one of way to reduce the cost of promoting drugs. Online shop is less complexity than a store. They can hire some doctors, pharmacists; and operators rather than to employ many shopkeepers in one store. For the consumer, they can save their money for expensive fee consultation and visiting healthcare. In some countries it is very expensive to get health consultation, while in other countries are free.

\section{c) Simple and Convenience Transac- tion}

Consumers are easily on dealing with the physician on the internet-based medical consultation. By using personal computer (PC), laptop, or mobile phone they can simply having such consultation. In some cases, consumers who have contracted a sexually transmitted disease are unwilling to get normal consultation when he or she has to meet the doctor. They are aware of their privacy and confidentiality if meeting face to face with the physicians. Taking the simply transaction is benefit for pharmacies or drug stores because they will get more consumer by serving direct transaction. Opening the online store 24 hours in a day means greater benefit for the web hosting because they can access the consumer unlimited.

\section{d) Updated information}

The main characteristic of using online media is easily for updating information and also delivered to all people rapidly. It is important to share all updating information for the interest of consumer's safety and healthy.

\section{e) Providing space for consumer's feedbacks}

Feedback from the consumer is a positive input for industrial pharmacy in evaluating and improving the quality and quantity of products. Consumer's feedbacks can be captured quickly by giving an online space on the website. However, the level of security should be anticipated so that the space is not misused by business competitors and consumers who are not well intentioned. 
3. Shortcoming of Using Internet-based Medical Consultation

\section{a) Ethical Problems}

The ethical problem can be considered by looking at the impact on trust (as a precondition for health care) of an online relationship, and follow with an assessment on the prevention of harm and injustice and confidentiality. Moreover, the aspect of acting in the patient's best interests, and whether online consultations can provide the reassurance to the patient needs.

\section{b) Legal Problems}

Some legal issues are concerned with the liability for the patient care medical malpractice (in light of the extent to which a duty of care in an online consultation is comparable to that which exists in the traditional doctor-patient relationship), negligence and contractual obligations, confidentiality of patent information, data protection regarding the security of medical data, and jurisdiction issues (related to the relative locations of an online doctor and a consumer, and bringing a claim against an online doctor). ${ }^{6}$ Liability arises between consumers and web hosting. Liability also addresses to the doctor because his or her status as an expert to be an employee of the web hosting who offers medical consultation. There are two models doctor in this relation: (a) doctor in: full time doctor and (2) doctor out: part time doctor.

For doctor in, he or she only works at the institution, because of labour relationship between employers and employees, the liability is on the institution. Famous doctrine which explaining this relation is Vicarious Liability (Respondent Superior). ${ }^{7}$ Doctor out will take the liability by his or herself on the interaction with consumers. Legal problem about the products is illegal or unethical pharmacies sometimes send out-dated, substituted, or counterfeit medications. Sometimes an online pharmacy may not be located in the country that is claimed. Other concerns include potential lack of confidentiality, improper packaging, inability to check for drug interactions, and several other issues.

\section{c) Competency}

The internet-based consultations, by their very nature, do not involve a physical examination in person by a licensed physician. Therefore, they may be dangerous both in terms of making a correct diagnosis and determining drug interactions. ${ }^{8}$ The illegal and bad practices in this case are physicians/ doctors who issue online prescriptions ("cyber doctors") are either not licensed to practice medicine in the consumer's state/country or are not credible. Pharmacies recruited many cyber doctors recruited by internet pharmacies were previously unemployed, semi-retired, or had declining practice incomes.

\section{d) Consumer's Economic Interest}

Consumer must be noted that offered price on the internet-based medical consultation must not be regarded as the leading consideration. If they don't know that they will be receiving the actual medication that was prescribed for them, they must put safety ahead of price. ${ }^{9}$ When consumer gets improper medication because of non face-to face interaction, the next consequence is they have to pay more on the recovery process.

4. Physicians, Pharmacists, Pharmaceutical Companies, Web Hosting, and Governments: Inter-Related and Overlapped Interest

The internet-based Medical Consultation involves physicians, pharmacists, pharmaceutical companies, Web Hosting, consumers, and govern- 
ment bodies built up such a relationship from a simple to the complex net connections. Every party on this relation has their own interest, goal and sometimes it can be overlapped one for another.

\section{a) Physician}

The interests of doctors in practiceroom or virtual are actually the same. They have to provide medical care for the patient (consumer) in achieving healthier condition. On the internet-based medical consultation, their interest to give the best treatment to consumer are conflicting with other parties' interest. The fact that physician is working for industrial pharmacy or web hosting will affect him to prescribe certain drugs and consulting a large number of consumers without adequate medication.

\section{b) Pharmacist}

The practice of pharmacy is growing steadily more complex. Medications have become increasingly essential to treating disease, and each year brings the introduction of ever more sophisticated drugs. Pharmacists have an essential role in medication use through counselling patients on the proper medication use; advising physicians, nurses, and other health care providers on medication therapy management; and working collaboratively with physicians. It is no surprise that pharmacy is one of the most highly regulated health professions. ${ }^{10}$

\section{c) Pharmaceutical Company}

The pharmaceutical company as well as industry in general aimed at the pursuit of profits. In the pharmaceutical industry's point of view, drug sales by opening an online store are one of marketing methods. Reaching a wider market with more profit is the main goal of online store. This goal is often so dominant that the pharmaceutical industry pays little attention to the weaknesses of this system from the standpoint of drug consumers. For examples: What should we do if the system does not provide sufficient information for the consumer? How will accountability for this? Is it possible to make complaints if consumers are getting problems with transactions? Direct consumer promotion of prescription drug is allowed in US where it has become increasingly common during the late 1980s and the 1990s, but not in other industrialized countries. ${ }^{11}$

\section{d) Web Host}

Web host is company that provides space on a server. It owns or leases for the use by its clients as well as providing the internet connectivity, typically in a data center. Web host can also provides data center space and connectivity to the internet for servers they do not own to be located in their data center. The interest of web host in this internet-based medical consultation is to get income from facilitating other parties on such transaction. If Web Host is independence, it can provide the service for several pharmacy companies, doctors and pharmacists. Some Web Hosts are part of pharmaceutical company, which has the same goals on running this model of transaction.

\section{e) Government}

In the conflict of interest between business interest and consumer, imbalance on bargaining position of them, the stronger profit oriented of pharmacy and Web Host than concerning about consumer safety, the government is required to intermediate between the parties. Considering that condition United Nations Guidelines for Consumer Protection (as expanded in 1999) government taking into account the interests and needs of consumers in all countries, particularly those in developing countries; recognizing that consumers often face imbalances in economic terms, educational levels and bargaining power; and bearing in mind that consumers should have the right of access to 
non-hazardous products, as well as the right to promote just, equitable and sustainable economic and social development and environmental protection. ${ }^{12}$

These guidelines for consumer protection have the following objectives on Pharmaceuticals governments should develop or maintain adequate standards, provisions and appropriate regulatory systems for ensuring the quality and the appropriate use of pharmaceuticals through integrated national drug policies, which could address, inter alia, procurement, distribution, production, licensing arrangements, registration systems and the availability of reliable information on pharmaceuticals.

In so doing, Governments should take special account of the work and recommendations of the World Health Organization on pharmaceuticals. For relevant products, the use of that organization's Certification Scheme on the Quality of Pharmaceutical Products Moving in International Commerce and other international information systems on pharmaceuticals should be encouraged. Measures should also be taken, as appropriate, to promote the use of the international non-proprietary names (INNs) for drugs, drawing on the work done by the World Health Organization. ${ }^{13}$

\section{f) Consumer}

Consumer's main interest is aimed to get the best treatment for improving health. Internet-based on medical consultation is the alternative choice than going to the General Practitioner. This alternative way gives benefit when the nearby healthcare are closed or the medical is not available on the nearby pharmacy. When the medication is processing to reach better condition, this significant issue about health and safety is the main consideration. ${ }^{13}$

\section{g) Consumer Health and Safety}

The safety of the patient is a fundamental principle of the health care service. Yet, every point in the process of care-giving contains a certain degree of inherent unsafely. Consumer safety emphasizes the central role of the patients and consumers, who should crucially play in efforts to improve the quality and safety of health service around the world.

Sampling case of consumer's safety is incorrect use of medicines. World health Organization (WHO) estimates that more than half of all medicines are prescribed, dispensed or sold inappropriately, and that half of all patients fail to take them correctly. This incorrect use may take the form of overuse, underuse and misuse of prescription or non-prescription medicines. Incorrect use of medicines occurs in all countries, causing harm to people and wasting resources. Consequences include: antimicrobial resistance, adverse drug reactions and medication errors, lost resources and eroded patient confidence. ${ }^{14}$ What factors contribute to incorrect use of medicines in the context of online medical consultation? (1) inappropriate unethical promotion (over promotion) of medicines by pharmaceutical companies; (2) profits oriented from selling medicines; (3) unrestricted availability of medicines; (4) overworked health personnel (online doctor, online pharmacist); and (5) lack of national pharmaceutical policy and law.

Facing that problem, on the guidelines for consumer protection that governments should adopt or encourage the adoption of appropriate measures, including legal systems, safety regulations, national or international standards, voluntary standards and the maintenance of safety records to ensure that products are safe for either intended or nor- 
mally foreseeable use. ${ }^{15}$

Moreover on regulation about standards for the safety and quality of consumer goods and services governments should, as appropriate, formulate or promote the elaboration and implementation of standards, voluntary and other, at the national and international levels for the safety and quality of goods and services and give them appropriate publicity. National standards and regulations for product safety and quality should be reviewed from time to time, in order to ensure that they conform, where possible, to generally accepted international standards. ${ }^{16}$ Where a standard lower than the generally accepted international standard is being applied of local economic conditions, every effort should be made to raise that standard as soon as possible. It is important for the governments to encourage and ensure the availability of facilities to test and certify the safety, quality and performance of essential consumer goods and services.

\section{Consumer's Right on the Internet-based Medical Consultation}

Consumer's basic rights firstly introducing by former US John F. Kennedy in front of US Congress on 15 March $1962 .{ }^{17}$ Hence, 15 March is commemorating as the Consumers' Day. This day has a historic importance as it was on this day in 1962, when the Bill for Consumer Rights was moved in the US Congress. During his speech, President John F. Kennedy had remarked: ${ }^{18}$

If a consumer is offered inferior products, if prices are exorbitant, if drugs are unsafe or worthless, if the consumer is unable to choose on an informed basis, then his dollar is wasted, his health and safety may be threatened, and national interest suffers.
John F. Kennedy had equated the rights of the ordinary American consumer with national interest. He gave the American consumer four basic rights: ${ }^{19}$

1. The Right to Safety - to be protected against the marketing of goods which are hazardous to health or life.

2. The Right to Choose - to be assured, wherever possible, access to a variety of products and services at competitive prices: and in those industries where competition is not workable and Government regulation is substituted, an assurance of satisfactory quality and service at fair prices.

3. The Right to Information - to be protected against fraudulent, deceitful or grossly misleading information, advertising, labelling, or other practices, and to be given the facts $\mathrm{s} /$ he needs to make an informed choice.

4. The Right to be heard - to be assured that consumer interests will receive full and sympathetic consideration in the formulation of Government policy, and fair and expeditious treatment in its administrative tribunals.

Kennedy recognized that consumers are the largest economic group in the country's economy, affecting and affected by almost every public and private economic decision. But they were also the only important group who were not effectively organized, whose views were not heard. ${ }^{20}$ The Consumers International (CI), former International Organization of Consumer Unions (IOCU), the umbrella body, for 240 organizations in over 100 countries, expanded the rights to eight points, which in a logical order reads: ${ }^{21}$ (1) basic needs; (2) safety; (3) information; (4) choice; (5) representation; (6)

\footnotetext{
The Economic and Social Council of United Nations, "Guidelines for Consumer Protection”, http://www.un.org/documents/ecosoc/res/1999/ eres 1999- 7.htm, accessed on 6 August 2013.

World Health Organisation, Ibid.

Sidharta, 2004, Consumer Protection, Grasindo, Jakarta, p. 44.

Consumer Unity \& Trust Society (CUTS), "Consumer Rights and Its Expansion Rights and Responsibilities", http://www.consumersinternational.org/whowe-are/consumer-rights, accessed on 6 August 2013.

Ibid.

20 Consumers International, "Consumer Rights”, http://www.consumersinternational.org/whowe-are/consumer-rights, accessed on 6 August 2013. 
redress; (7) consumer education and (8) healthy environment.

Concerning their relation on internet-based medical consultation, consumer needs these following essential rights:

1) The availability of an adequate information

Information is primarily needed as a basic consideration when somebody enters into a transaction. Consumer needs relevant information of good quality on benefits and harms related to the available options, presented in a way that enables them to choose appropriate treatment together with the doctor, and to manage their treatment subsequently. Drug and treatment information directed to the public, in whatever form (including online on websites), should be balanced in its account of benefits and harms. Trustworthy sources should be mandated to provide balanced information in a readily accessible and understandable form. Such information should aim to support good doctor-patient (consumer) interactions.

The World Health Organization regulating that an advertising is one form of promotion, partial in its selection of information, usually with commercial benefit to the promoter as its sole or principal intent. The information must be scientifically valid, upto-date and balanced. It should allow comparisons between drug and non-drug treatments, and the option of no treatment. Facts, hypotheses and conclusions should be distinguished, uncertainty acknowledged. Sources of information, and their particular should be identified, including all potential conflicts of interest. ${ }^{22}$ Information of any kind must never damage, distort or subvert the true interest of public health, or the essential needs of individual welfare. Adequate information is similar to ideal information which meet with this following criteria: objective (academic accountability/scientifically), complete (do not hide the risk of treatment), not misleading (directing user to misperception that can lead to mistakenly used). ${ }^{23}$

2) The safety of products

The right of safety product is essential for consumer's life. It is a guarantee that consumer will save their body consuming service (consultation) and the products (drugs). ${ }^{24}$ Pharmaceutical products (more commonly known as medicines or drugs) are a fundamental component of both modern and traditional medicine. It is essential that such products are safe, effective, and of good quality, and are prescribed and used rationally. ${ }^{25}$

3) The right to choose facing the physician's decision

Doctor-patient (consumer) relationship is a relationship built on trust. The patient believed that he visited a doctor (even online meeting) to alleviate his or her illness, no matter how the way in which a doctor. The pattern of such relationships closely to the psychological aspect conducted therapeutic transaction.

Basically, the consumer has the right autonomy to choose when faced with decisions about the treatment of the doctor. This means that consumer have autonomy to take decisions related to his or her body. This fundamental rights is based on human rights the rights to self determination as mentioned in Article 3 The Universal Declaration of $\mathrm{Hu}-$ man Rights 1948, "Everyone has the right to life, liberty and security of person". ${ }^{26}$

Autonomy is about respecting patients'

\footnotetext{
Mintzes, et al., "The Influence of Direct to Consumer Pharmaceutical Advertising and Patients' Requests on Prescribing Decisions: Two Site Cross Sectional Survey", www.bmj.com, accessed on 6 August 2013.

23 Chris J. van Boxtel, et al., 2001, Drug Regulation: Organization and Control in Drug Benefits and Risks: International Textbook of Clinical Pharmacology, John Wiley\& Sons Ltd. Baffins Lane, Chichester West Sussex, p. 70.

Miru Ahmadi, et al., 2004, Consumer Protection Law, Radja Grafindo Perkasa, Jakarta, p. 41.

World Health Organisation, Ibid.

United Nations, "The Universal Declaration of Human Rights", http://www.un.org/en/documents/udhr/, accessed on 6 August 2013.
} 
wishes and facilitating and encouraging their input into the medical decision-making process. To respect a consumer's autonomy is to give that individual a greater balance of power in the doctor-patient (consumer) relationship. It entails explaining not only what is wrong with that person, but also the options and implications of any proposed investigation and treatment and the associated risks and benefits. The practitioner needs to provide the patient with as much information as he or she both wishes for and requires in order making a decision.

\section{4) The right to be heard on complaints}

The right to be heard is consumer's right to get loss and damage on their medical consultation. They have to be heard regarding the service of the interest of their heath improving and a chance to redress the drug product. There should be establish or maintain legal and/or administrative measures to enable consumers to be heard through formal or informal procedures that are expeditious, fair, inexpensive and accessible. There also should be encourage all enterprises to resolve consumer disputes in a fair, expeditious and informal manner, and to establish voluntary mechanisms, including advisory services and informal complaints procedures, which can provide assistance to consumers. Information on dispute-resolving procedures should be made available to consumers.

5) The implementation of the medical ethics

Achieving the betterment relationship between any parties on online medical consultation can be forced not only by consumer law but also trough medical ethic. Medical ethics is a discipline/methodology for considering the implications of medical technology/treatment and what ought to be. ${ }^{27}$

Medical ethic should be implemented on the process are: ${ }^{28}$ a. Autonomy and respect for autonomy Autonomy literally means self-governance. It is valued because trough autonomy that our character is shaped. In the exercise of our autonomy that makes us the person we are and provide us with our dignity.

b. Beneficence and non-maleficence The central moral objective of medicine is to produce net medical benefit for the patient with as little harm as possible.

c. Justice

In this medical context justice refers to fairness or equity and not to lawfulness.

d. Veracity

Traditionally, truth-telling has not received prominence in healthcare relationships. This argument is that the healthcare professional is justified in lying to a patient when the deception is used for the patient's benefit.

Furthermore, implementation of four main goals of medicine, there are: ${ }^{29}$

a. The prevention of disease and injury and the promotion and the maintenance

b. The relief of pain and suffering caused by maladies

c. The care and cure of those with malady, and the care of those who cannot be cured

d. The avoidance of premature death and the pursuit of peaceful death.

\section{Dispute Settlement between Consumers to Other Parties: Implementation on Which Jurisdiction?}

The internet across geographic and state boundary creates a global market for commerce. Thus relatively easy for a medical practitioner to be located and registered within one jurisdiction although their consumer located in a different jurisdiction. But it would be a problem if the standard of license is different from other country. The practice of medication within any jurisdiction without an appropriate license is a criminal offence, since it 
places citizens at a serious risk.

However, it is difficult to prosecute a medical practitioner successfully located in a different jurisdiction from consumer. This is especially true where it is prohibitively expensive to do so or where the appropriate legal agreements between jurisdictions (especially countries) are not exist. To solve the problem the countries usually use several rules of Private International Law. But it still remains the problem of execution on implementation. We can also use Alternative Dispute Resolution (ADR).

ADR is a term used to cover a wide variety of dispute resolution methods, such as mediation (mediation is peaceful settlement or compromise between parties trough the benevolent intervention of an impartial third party ${ }^{30}$ ), arbitration (arbitration is the process by which parties to a dispute submit their difference to the binding judgment of an impartial third person or group selected by mutual consent $^{31}$ ) and complaints assistance, all of which are alternatives to court action. Other terms that can be used for this are "extra-judicial dispute resolution" or appropriate dispute resolution".

Online Dispute Resolution (ODR) is ADR services offered entirely by electronic means, without the need of the disputing parties to leave their homes/offices or disputes in cyberspace or online dispute resolution for consumers in cross-border disputes. But the online context raises new challenges for those conducting the dispute resolution (the so-called dispute resolution officers), who can no longer rely, for example, on subtle pressure possible in a face-to-face context. Common weaknesses include limited availability (both in terms of merchants and language), high cost to consumers, failure to include adequate consumer representation on the governing board, lack of transparency (in terms of result records and officials' credentials), lack of scale ability (adapting the service to the nature of the dispute),

\section{Conclusion}

The model of the internet-based medical consultation is the ease of transaction with many advantages. But on the other sides, the risk especially for protecting consumer's health and safety cannot be ignored. This model of transaction is not only an opportunity but also a challenge when positioning consumer in imbalance position with the other related parties (webhost, physician, pharmacist, Pharmacy Company, and the government). Every party has its own interest that can create conflict of interest with decrease the priority of consumer's protection.

Facing this problem, the role of government in balancing the condition is so crucial trough regulating on inter-relationship. Continuously developing on the internet-based medical consultation is needed by the basic values of ethical and legal perspective since the promotion, transaction, until the dispute settlement process. The importance of consumer's basic rights are the availability of an adequate information, the safety of products, the right to choose facing the physician's decision, the right to be heard on complaints and the implementation of the medical ethics, which is a form of respectfully on this transaction. Because the object is being health, which is regarded as the utmost important aspect in the human life.

\section{REFFERENCES}

\section{A. Books}

Ahmadi, Miru, et al., 2004, Hukum Perlindungan Konsumen, Radja Grafindo Perkasa, Jakarta. August, Ray, 1993, International Business Law, Text, Cases and Readings, Prentice Hall Inc., New Jersey.
Boxtel, Chris J. van, et al., 2001, Drug Regulation: Organization and Control in Drug Benefits and Risks: International Textbook of Clinical Pharmacology, John Wiley\& Sons Ltd. Baffins Lane, Chichester West Sussex.

Darvey, Diane L., 2008, Legal Handbook for Phar- 
macy Technicians, American Society of Health Pharmacists, New York.

Fred, Ameln,1991, Medical Law, Grafikajaya, Jakarta.

George, Carlisle, et al., 2008, UK Online Medical Consultations: Legal, Ethical, and Social Perspectives on UK Ethical, Legal, and Social Issues in Medical Informatics, Medical Information Science Reference Hershey, New York.

Maclean, Alasdair, 2004, Briefcase on Medical Law, Cavendish Publishing, London.

Sari, Norma, 2011, The Role of Communication and Information Technologies in Medicine and Treatment on Supporting Patient's Protection, Graha Ilmu, Yogyakarta.

Sidharta, 2004, Perlindungan Konsumen, Grasindo, Jakarta.

Vincler, Lisa A., 1998, Ethics in Medicine, University of Washington School of Medicine, Washington.

\section{B. Internet}

Consumers International, "Consumer Rights", http://www.consumersinternational.org/ whowe-are/consumer-rights, accessed $6 \mathrm{Au}-$ gust 2013.

Consumer Unity \& Trust Society (CUTS), "Consumer Rights and Its Expansion Rights and Responsibilities", $\mathrm{h} t t p: / / w w w . c o n s u m e r s-$ international.org/ whowe-are/consumerrights, accessed 6 August 2013.
Health Action International, "Blurring the Boundaries", http://www.haiweb.org/pubs/blurring/ blurring.ch1.html, accessed 6 August 2013.

Henney, J., "Online Pharmacies-Maintaining the Safety Net. Medscape Pharmacists", http:// www.medscape.com, accessed 23 September 2013.

Khan, Amir, "Internet Pharmacies Get go-ahead", http://news.bbc.co.uk/2/hi/health/3572620. stm, accessed on 6 August 2013.

Larson, Aaron, "Law Office Aaron: Online Pharmacy", http://www.expertlaw.com/library/ consumer/online pharmacy.html, accessed 6 August 2013.

Mintzes, et al., "The Influence of Direct to Consumer Pharmaceutical Advertising and $\mathrm{Pa}-$ tients' Requests on Prescribing Decisions: Two Site Cross Sectional Survey", http:// www.bmj.com, accessed 6 August 2013.

The Economic and Social Council of United Nations, "Guidelines for Consumer Protection", http://www.un.org/documents/ecosoc/ res/1999/eres1999- 7.htm, accessed 6 August 2013.

United Nations, "The Universal Declaration of $\mathrm{Hu}-$ man Rights", http://www.un.org/en/documents/udhr/, accessed 6 August 2013.

World Health Organisation, "Health Services", http://www.who.int/topics/health_services/ en/, accessed on 6 August 2013. 